\title{
Design and Evaluation of Ondansetron Fast Disintegrating Tablets Using Natural Polymers and Modified Starches as Super Disintegrants for the Enhancement of Dissolution
}

\author{
Sravanthi Mulagada, Srinivasa Rao Baratam* \\ Assistant Professor, Department of Pharmaceutical Technology, St. Ann's College of Pharmacy, Vizianagaram. Pin 535003, Andhra Pradesh, INDIA.
}

\begin{abstract}
Objective: Ondansetron is an anti-emetic drug which is insoluble in water; hence the drug may be slowly or incompletely dissolves in the gastrointestinal tract. So the rate of dissolution and therefore its bioavailability is $60 \%$. The present study is to formulate and evaluate fast disintegrating tablets of ondansetron by direct compression method employing natural polymers and modified starches as super disintegrating agents Methods: In the present study an attempt has been made to prepare fast Disintegrating tablets of Linseed, Isapgol, Sodium starch glycolate and Pre gelatinized starch used in the level of addition to increase the rate of drug release from dosage form to increase the dissolution rate. Direct Compression method was used to formulate the tablets. Results: All the formulations were showed the acceptable flow properties and the pre compression parameters like Bulk density, Tapped density and Carr's compressibility index and Hausner ratio. The post compression parameters like Weight variation, friability, hardness, disintegration, wetting time, water absorption ration, and In vitro dissolution profile values were found to be within specified limits. FTIR Studies shows no interaction between Drug and excipients. Conclusion:
\end{abstract}

From the data obtained, it is observed from the formulation containing Isapghol in Formulation F9, shows Disintegration time in 12 seconds and the Percentage drug release is of $99.10 \%$ at the end of 30 min which satisfied all the tablet evaluation parameters for fast disintegrating tablet.

Key words: Direct Compression, Ondansetron, Modified Starches, Natural Polymers, Fast Disintegrating Tablets.

Key message: Fast Disintegrating Tablets.

Correspondence :

Srinivasa Rao Baratam, M.Pharm.,(Ph.D)., Assistant Professor, Department of Pharmaceutical Technology, St. Ann's College of Pharmacy, Vizianagaram, Pin 535003, Andhra Pradesh, INDIA.

Phone: +91-9441389610

Email: srinivas.baratam077@gmail.com

DOI: 10.5530/jyp.2017.9.101

\section{INTRODUCTION}

Despite of tremendous innovations in drug delivery, the oral route remains the preferred route for administration of therapeutic agents because of accurate dosage, low cost therapy, self-medication, and ease of administration leading to high level of patient compliance. The most popular dosage forms are being conventional tablets and hard gelatin capsules. Pediatric and geriatric patients may have difficulties in swallowing or chewing pharmaceutical dosage forms for oral administration. ${ }^{1}$ FDTs ( Fast dissolving/dispersing/disintegrating tablets) are novel types of tablets that dissolve/ disintegrate/disperse in saliva within few seconds without water. ${ }^{2}$ The FDT formulation is defined by the Food and Drug Administration (FDA) as a solid dosage form containing medical substances whish disintegrates rapidly, usually within a seconds, when placed upon the tongue. Ondansetron has a high oral bioavailability of $60 \%$. The half-life is $7 \mathrm{~h}$ and the $\mathrm{T}_{\max }$ is $1.5 \mathrm{~h}$ for the conventional tablet and slightly longer for the oral drug therapy (ODT). In cancer chemotherapy, drug induced nausea and vomiting may occur so regularly that anticipatory vomiting occurs when patients return for treatment before the chemotherapeutic agent is given. If not controlled, the discomfort associate with drug induced emesis may cause a patient to refuse further chemotherapy. In this condition ondansetron hydrochloride is a drug of choice. ${ }^{3,4}$ In the bio pharmaceutical classification system, ondansetron is classified as BCS (Biopharmaceutical Classification system) II drug, because of its low water solubility and high permeability. ${ }^{5}$ In the present study, natural polymers, modified starches are patient friendly dosage form was developed as a fast disintegrating tablet containing ondansetron. Natural polymers are pathological products, readily dissolve in water.
Hence, Linseed, Isapgol, Pre gelatinized starch and Sodium starch glycollate are selected for the development of fast disintegrating tablets.

\section{MATERIALS AND METHODS}

\section{Materials}

Ondansetron, Linseed, Isapgol, Pre gelatinized Starch were obtained from Yarrow Chem. Products, Mumbai. All other chemicals were of reagent grade and used without purification.

Preparation of seeds powder of Linseed (Plantego ovate), Linseed (Linum usitatissimum)

The dried Plantego ovata seeds and Linum usitatissimum were comminuted and sieved through mesh no. 80 and stored in desiccators. ${ }^{6}$

\section{Preparation of fast disintegrating tablets of ondansetran using direct compression method}

Fast disintegrating tablets of ondansetron containing different concentrations of super disintegrants were be prepared by direct compression method. First the powders of natural super disintegrants was screened through mesh no.60 individually and kept aside. The drug, super disintegrants, diluents, binder, talc, magnesium stearate was mixed in mortar and pestle to form a uniform blend and finally they are passed through mesh no. 60 and the formulations were shown in Table 1 Powder thus obtained was compressed into tablets on an 8 station single punch rotary tablet compression machine. ${ }^{7,8}$ 


\section{Fourier Transformer Infrared Spectral analysis}

Compatibility studies of ondansetron and the disintegrants were carried out by using Fourier Transform Infrared Spectroscopy (FTIR). Fourier transform infrared spectra of the samples were obtained in the range of 4000 to $450 \mathrm{~cm}-1$ using a FTIR by the $\mathrm{KBr}$ disc method. ${ }^{9}$

\section{Uniformity of weight}

The 20 randomly selected tablets were weighed individually; the average weight and the standard deviation were calculated. ${ }^{10}$

\section{Drug content}

Weighed tablets (5) were powdered using a glass mortar and pestle. An accurately weighed quantity of powder equivalent to $40 \mathrm{mg}$ of ondansetron was taken into $100 \mathrm{ml}$ volumetric flask, dissolved in phosphate buffer of $\mathrm{pH} 6.8$ and the solution was filtered through whatsman filter paper no.41. The filtrate was collected and suitably diluted with phosphate buffer of $\mathrm{pH}$ 6.8. The drug content was Determined at $310 \mathrm{~nm}^{.1}$

\section{Friability test}

Friability of the tablets was determined using Roche friabilator at $25 \mathrm{rpm} / \mathrm{min}$ for $4 \mathrm{~min}$. 40 tablets were weighed and loss in weight (\%) was calculated. ${ }^{12}$

Friability $=\left(\mathrm{W}_{1}-\mathrm{W}_{2}\right) / \mathrm{W}_{1} \times 100$

Weight of 40 Tablets $=\mathrm{W}_{1}$,

Weight of 40 Tablets after friability $=\mathrm{W}_{2}$

\section{Wetting time}

The wetting time of the tablets was measured using a simple procedure. Five circular tissue papers of $10-\mathrm{cm}$ diameter were placed in a petridish with a $10-\mathrm{cm}$ diameter. Ten milliliters of water containing eosin, a water-soluble dye, was added to the petridish. A tablet was carefully placed on the surface of tissue paper. The time required for water to reach the upper surface of the tablets was noted as the wetting time. The wetting times were measured. ${ }^{13}$

\section{Water Absorption Ratio}

A piece of tissue paper folded twice was placed in a small Petri dish containing $6 \mathrm{ml}$ of water. A tablet was put on the tissue paper and allowed to completely wet. The wetted tablet was then weighed. Water absorption ratio, $\mathrm{R}$ was determined using following equation. ${ }^{14}$

$$
\mathrm{R}=100 \times\left(\mathrm{W}_{\mathrm{a}-}, \mathrm{W}_{\mathrm{b}}\right) / \mathrm{W}_{\mathrm{a}}
$$

Where, $\quad \mathrm{W}_{\mathrm{a}}=$ Weight of tablet after water absorption

$$
\mathrm{W}_{\mathrm{b}}=\text { Weight of tablet before water absorption. }
$$

\section{In vitro disintegration test}

The in vitro disintegration studies were carried out using a digital tablet disintegration test apparatus. One tablet was placed in each of the 6 tubes of the basket assembly and then disk was added to each tube. This assembly was then suspended in a 1-liter beaker containing water with its temperature being maintained at $37 \pm 2^{\circ} \mathrm{C}$. The basket was then moved up and down through a distance of 5 to $6 \mathrm{~cm}$, at the frequency of 28 to 32 cycles per minute. The time required for complete disintegration of the tablet was recorded.$^{15}$

\section{Dissolution study}

The release rate of ondansetron from fast disintegrating tablets was determined by using USP (Lab India, DS 8000) dissolution testing apparatus II (paddle method). The dissolution test was performed using $900 \mathrm{ml}$ of $\mathrm{pH} 6.8$ buffer as a dissolution medium, at $37 \pm 0.5^{\circ} \mathrm{C}$ and $50 \mathrm{rpm}$. A sample $(5 \mathrm{ml})$ of the solution was withdrawn from the dissolution apparatus at $0,5,10,15,20,25$ and 30 minutes. The samples were filtered through a 0.45 membrane filter. Absorbance of these solutions was measured at $310 \mathrm{~nm}$ using a Elico-210 spectrophotometer. Cumulative percentage of drug release was calculated using an equation obtained from a standard curve. ${ }^{16}$

\section{RESULTS AND DISCUSSION}

\section{Drug content}

The ondansetron tablets were tested for drug content by UV method, the percentage drug content was found to be in between 98 to $101.37 \%$ and the results were shown in Table 3 .

\section{Fourier Transform Infra-red spectral analysis}

The FTIR spectra of ondansetron and optimized formulation were shown in Figure 1\&2. The results obtained with IR studies showed that there was no interaction between the drug and other excipients used in the formulation. The FTIR of ondansetron has shown intense band at $3483.41 \mathrm{~cm}-1,2910.11 \mathrm{~cm}-1$, and $1638.7 \mathrm{~cm}-1$ corresponding to the presence of functional groups such as $\mathrm{NH}$ group, C-C-Aromatic group and C-C-Aliphatic group. The FT-IR of optimized formulation has shown intense bands at $3483.93 \mathrm{~cm}-1,2925.03 \mathrm{~cm}-1$, and $1637.96 \mathrm{~cm}-1$ which indicate no change in the functional groups such as $\mathrm{NH}$ group, C-C-Aromatic group, C-C-Aliphatic and confirmed undisturbed structure of ondansetron, which indicates no drug-excipient interaction as shown in Figure $1 \& 2$.

\section{Evaluation of pre formulation studies of drug excipient powder}

The Bulk density of various powder mixed blends prepared with different super disintegrants, was measured by graduated cylinder. The bulk density was found in the range $0.369-0.0 .549 \mathrm{gr} / \mathrm{ml}$. The Tapped density of various powder mixed blends prepared with different super disintegrants, was measured by graduated cylinder. The Tapped density was found in the range $0.5150-0.648 \mathrm{gr} / \mathrm{ml}$. The Compressibility index of various powder mixed blends, prepared with different super disintegrants, using bulk density and tapped density data, compressibility index was calculated. It was found in the range 14.29- 29.40\%.The Hausner's ratio of various powder mixed blends, prepared with different super disintegrants, using bulk density and tapped density data, Hausner's ratio was calculated. It was found in the range 1.22- 1.41. Angle of repose ranged from 30.64-33.03. The flow properties of powder blend in all formulations exhibit good flow and passable characteristics. Average Weight variation of tablets was found in range 391.57- $397.36 \mathrm{mg}$. Hardness of the tablets was found in the range $3.0-3.3 \mathrm{Kg} / \mathrm{cm}^{2}$.Pre compression parameters were shown in Table 2.

\section{Characterization of fast disintegrating tablets}

Tablets were evaluated by using Roche friabilator and friability of tablets was observed in the range $0.31-0.88 \%$. Tablets were evaluated for disintegration time in the disintegration apparatus. The disintegration time was found in the range 12- $56 \mathrm{sec}$. Tablets were evaluated for wetting time test. The wetting time was found in the range $54-59 \mathrm{sec}$. Post compression parameters were shown in the Table 3.

All the formulations were uniform in drug content and the FTIR spectra of ondansetron and its fast disintegrating tablets are identical. The principle FTIR absorption peaks of ondansetron fast disintegrating tablets were observed and found to be identical with the spectra of ondansetron pure drug. Thus from the spectra it was understood that there was no interaction between ondansetron and the disintegrants used in the preparation of tablets. As the concentrations of the Isapghol increases in the formulations F7 to F9 the disintegration time found to be decreased and the disintegration time for these formulations were $25,13,12$ seconds respectively and the percentage drug release was also found to be increased for these formulations as $91.77,96.4,99.10 \%$ respectively. From the above results it was found that as the concentration 
Table 1: Master formula for preparation of ondansetron fast disintegrating tablets

\begin{tabular}{|c|c|c|c|c|c|c|c|c|c|c|c|c|}
\hline Ingredients & F1 & $\mathrm{F} 2$ & F3 & F4 & F5 & F6 & F7 & F8 & F9 & F10 & F11 & F12 \\
\hline Ondansetron & 8 & 8 & 8 & 8 & 8 & 8 & 8 & 8 & 8 & 8 & 8 & 8 \\
\hline Isapghol & 8 & 16 & 24 & - & - & - & - & - & - & - & - & - \\
\hline Linseed & - & - & - & 8 & 16 & 24 & - & - & - & - & - & - \\
\hline $\begin{array}{l}\text { Pre gelatinised } \\
\text { starch Rx } 1500\end{array}$ & - & - & - & - & - & - & 8 & 16 & 24 & - & - & - \\
\hline $\begin{array}{l}\text { Sodium starch } \\
\text { glycolate }\end{array}$ & - & - & - & - & - & - & - & - & - & 8 & 16 & 24 \\
\hline PVP K- 30 & 8 & 8 & 8 & 8 & 8 & 8 & 8 & 8 & 8 & 8 & 8 & 8 \\
\hline $\begin{array}{l}\text { Magnesium } \\
\text { stearate }\end{array}$ & 4 & 4 & 4 & 4 & 4 & 4 & 4 & 4 & 4 & 4 & 4 & 4 \\
\hline Talc & 4 & 4 & 4 & 4 & 4 & 4 & 4 & 4 & 4 & 4 & 4 & 4 \\
\hline MCC PH 102 & 368 & 360 & 352 & 368 & 360 & 352 & 368 & 360 & 352 & 368 & 360 & 352 \\
\hline Total weight in $\mathrm{mg}$ & 400 & 400 & 400 & 400 & 400 & 400 & 400 & 400 & 400 & 400 & 400 & 400 \\
\hline
\end{tabular}

Table 2: Pre compression Parameters of ondansetron fast disintegrating tablets

\begin{tabular}{cccccc}
\hline \multicolumn{5}{c}{ Pre compression parameters } \\
\hline Formulations & Angle of & Bulk & Tapped & Hausner's ratio & Carr's index (\%) \\
\hline F1 & repose $(\theta)$ & density $(\mathrm{gr} / \mathrm{ml})$ & density $(\mathrm{gr} / \mathrm{ml})$ & & 20 \\
F2 & 32.61 & 0.515 & 0.644 & 1.25 & 1.22 \\
F3 & 30.83 & 0.487 & 0.599 & 1.30 & 18.69 \\
F4 & 31.59 & 0.461 & 0.603 & 1.41 & 23.53 \\
F5 & 33.02 & 0.457 & 0.648 & 1.33 & 29.40 \\
F6 & 32.61 & 0.489 & 0.652 & 1.25 & 25 \\
F7 & 32.41 & 0.522 & 0.653 & 1.33 & 24.99 \\
F8 & 32.61 & 0.488 & 0.640 & 1.24 & 19.99 \\
F9 & 33.03 & 0.515 & 0.644 & 1.16 & 14.29 \\
F10 & 32.00 & 0.549 & 0.640 & 1.33 & 24.99 \\
F11 & 30.64 & 0.386 & 0.515 & 1.4 & 28.57 \\
F12 & 32.20 & 0.369 & 0.516 & 1.26 & 21.05 \\
\hline
\end{tabular}

Table 3: Post compression Parameters of ondansetron fast disintegrating tablets

\begin{tabular}{|c|c|c|c|c|c|c|c|}
\hline \multicolumn{8}{|c|}{ Post compression Parameters } \\
\hline Formulations & $\begin{array}{c}\text { Weight } \\
\text { variation(mg) }\end{array}$ & $\begin{array}{l}\text { Hardness } \\
(\mathrm{Kg} / \mathrm{cm} 2)\end{array}$ & $\begin{array}{c}\text { Friability } \\
(\%)\end{array}$ & $\begin{array}{l}\text { Disintegration } \\
\text { time (sec) }\end{array}$ & $\begin{array}{l}\text { Wetting } \\
\text { time (sec) }\end{array}$ & $\begin{array}{c}\text { Water } \\
\text { absorption } \\
\text { ratio (\%) }\end{array}$ & $\begin{array}{c}\text { Drug content } \\
(\%)\end{array}$ \\
\hline F1 & $394.77 \pm 1.2$ & $3 \pm 0.4$ & 0.62 & $50 \pm 3$ & $65 \pm 2.2$ & $51.60 \pm 2.1$ & $98.3 \pm 0.68$ \\
\hline F2 & $391.57 \pm 1.2$ & $3.3 \pm 0.1$ & 0.52 & $54 \pm 2$ & $55 \pm 2.2$ & $56.02 \pm 0.2$ & $98.6 \pm 0.43$ \\
\hline F3 & $397.05 \pm 1.2$ & $3.1 \pm 0.2$ & 0.53 & $56 \pm 2$ & $42 \pm 2.1$ & $58.87 \pm 5.1$ & $99 \pm 0.33$ \\
\hline F4 & $394.21 \pm 0.3$ & $3.3 \pm 0.1$ & 0.59 & $26 \pm 1$ & $20 \pm 1.2$ & $51.90 \pm 2.2$ & $98.44 \pm 0.6$ \\
\hline F5 & $392.15 \pm 1.0$ & $3.2 \pm 0.2$ & 0.62 & $30 \pm 2$ & $26 \pm 2.2$ & $53.51 \pm 5.2$ & $101.37 \pm 0.07$ \\
\hline F6 & $386.05 \pm 1.2$ & $3.0 \pm 0.1$ & 0.31 & $37 \pm 2$ & $35 \pm 0.1$ & $52.56 \pm 1.4$ & $99.22 \pm 0.06$ \\
\hline F7 & $396.10 \pm 1.0$ & $3.2 \pm 0.2$ & 0.88 & $25 \pm 1$ & $30 \pm 0.1$ & $55.10 \pm 1.6$ & $99.42 \pm 1.02$ \\
\hline F8 & $393.68 \pm 1.0$ & $3.2 \pm 0.1$ & 0.79 & $13 \pm 1$ & $25 \pm 0.1$ & $60.61 \pm 7.2$ & $99 \pm 0.25$ \\
\hline F9 & $395 \pm 1.1$ & $3.1 \pm 0.2$ & 0.53 & $12 \pm 5$ & $15 \pm 0.3$ & $64.10 \pm 4.2$ & $100.45 \pm 0.70$ \\
\hline F10 & $394.10 \pm 1.0$ & $3.0 \pm 0.1$ & 0.47 & $31 \pm 3$ & $27 \pm 1.2$ & $53.00 \pm 1.5$ & $99 \pm 0.82$ \\
\hline F11 & $396.73 \pm 1.1$ & $3.1 \pm 0.1$ & 0.64 & $20 \pm 2$ & $20 \pm 0.2$ & $54.71 \pm 0.1$ & $98 \pm 0.96$ \\
\hline F12 & $397.36 \pm 1.0$ & $3.1 \pm 0.2$ & 0.43 & $30 \pm 1$ & $35 \pm 0.2$ & $57.08 \pm 0.3$ & $99 \pm 0.59$ \\
\hline
\end{tabular}

${ }^{\star}$ Mean \pm S.D, $\mathrm{n}=3$ 


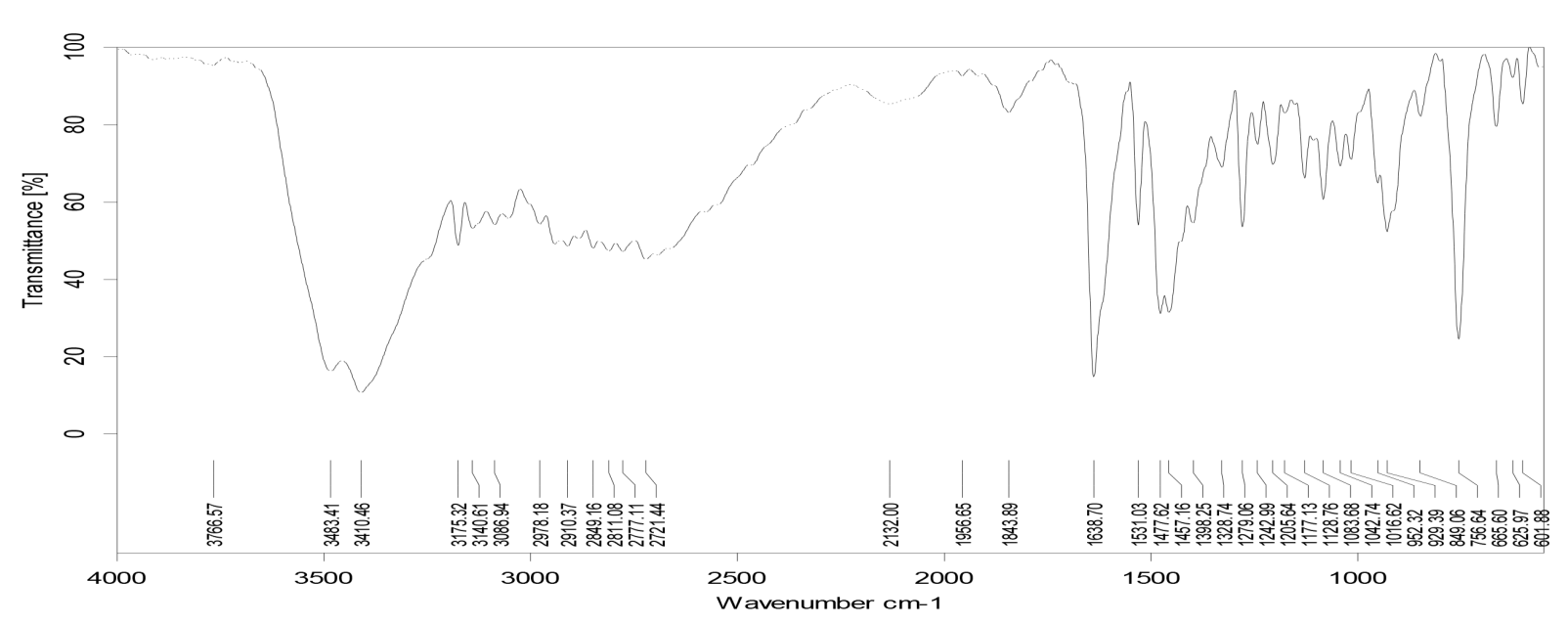

Figure 1: FTIR Spectra of ondansetron pure drug.

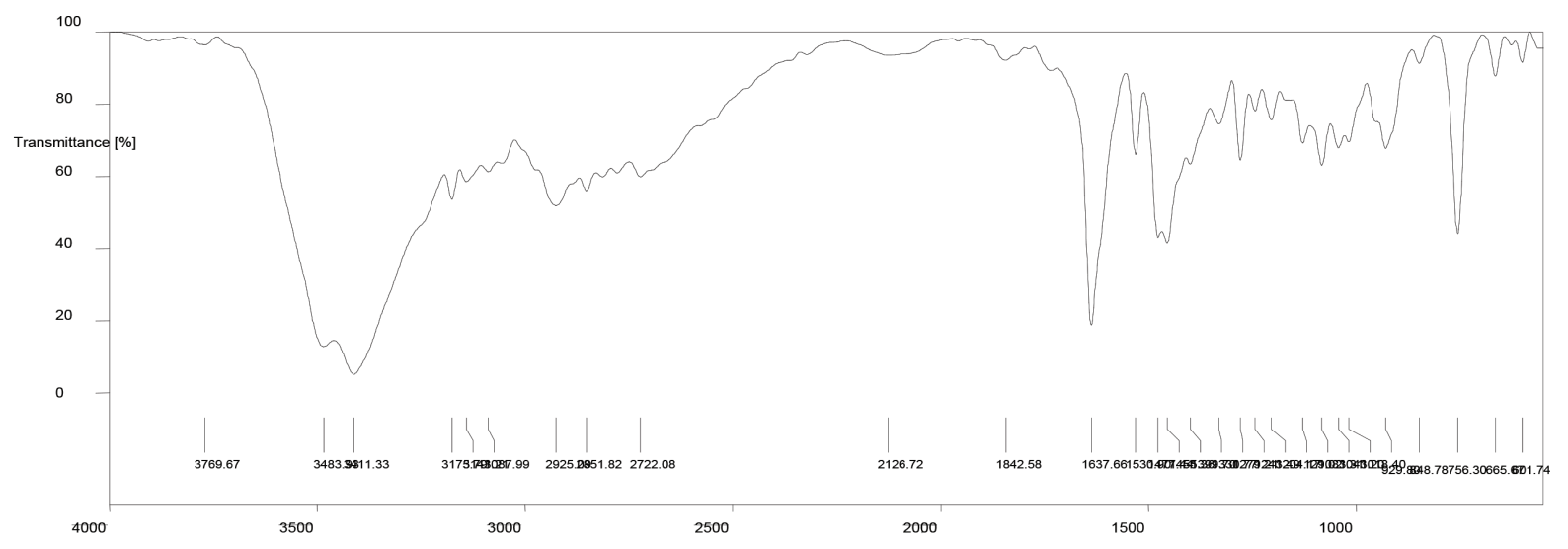

Figure 2: FTIR Spectra of ondansetron optimized formulation.

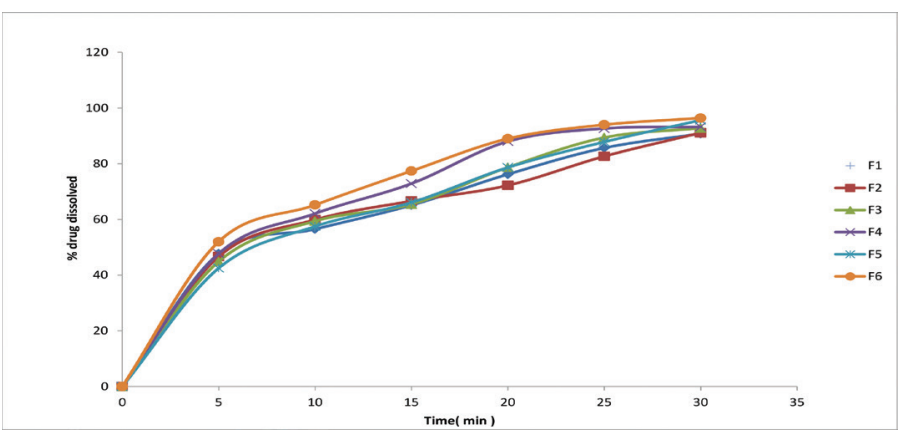

Figure 3: Dissolution of profiles of ondansetron formulation from F1 to F6.

of Isapghol increased and decreases the disintegration and dissolution time was found to be improved, so considering the above results it was found that the F9 batch was found to be optimized batch and it pass all the pre formulation parameters and evaluation results as per pharmacopeial limits

\section{Dissolution studies of fast disintegrating tablets}

To clarify the dissolution behavior of ondansetron formulation, the dissolution tests on ondansetron fast disintegrating tablets were carried

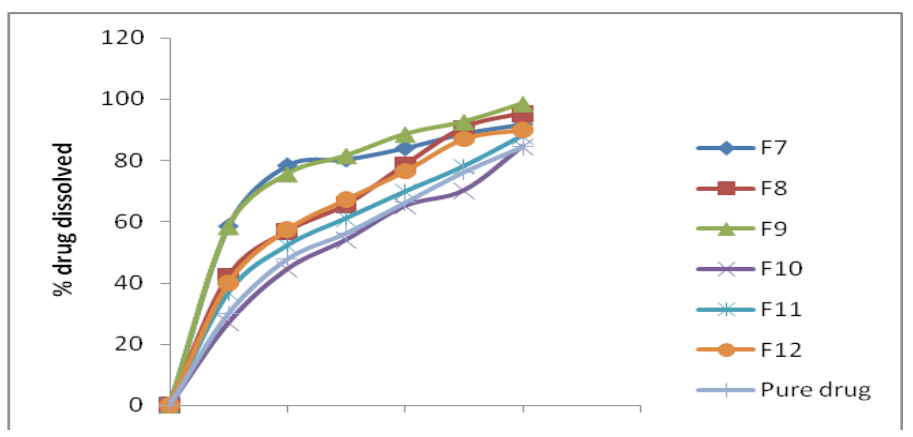

Figure 4: Dissolution of profiles of ondansetron formulation from F7 to F12 and pure drug.

out up to $30 \mathrm{~min}$ in phosphate buffer $\mathrm{pH}$ 6.8. Figure 3 and 4 shows the dissolution profile from $\mathrm{F} 1$ to $\mathrm{F} 12$ and pure drug. In vitro dissolution studies showed that more than $50 \%$ of the drug was released from the formulation within 10 minutes and were shown in Table 4. The rapid drug dissolution might be due to easy breakdown of particle by super disintegrant action. From in vitro dissolution data, it was observed that $99.10 \pm 0.67 \%$ of ondansetron released in 30 minutes indicates that the tablet complies as per pharmacopeial specifications. The drug release 
Table 4: Dissolution profiles of fast disintegrating tablets

\begin{tabular}{|c|c|c|c|c|c|c|}
\hline Time(min) & $\mathrm{F} 1$ & F2 & F3 & $\mathrm{F} 4$ & F5 & F6 \\
\hline 0 & 0 & 0 & 0 & 0 & 0 & 0 \\
\hline 5 & $47.7 \pm 0.93$ & $46.65 \pm 0.88$ & $44.88 \pm 0.78$ & $47.7 \pm 0.67$ & $42.5 \pm 1.3$ & $52 \pm 0.77$ \\
\hline 10 & $56.5 \pm 0.67$ & $59.89 \pm 0.82$ & $59.39 \pm 0.77$ & $62.1 \pm 0.99$ & $57.5 \pm 1.1$ & $65.2 \pm 0.83$ \\
\hline 15 & $65.1 \pm 1.20$ & $66.59 \pm 0.89$ & $65.45 \pm 0.91$ & $72.88 \pm 0.78$ & $66.1 \pm 0.91$ & $77.4 \pm 0.91$ \\
\hline 20 & $76.2 \pm 1.4$ & $72.22 \pm 0.67$ & $78.7 \pm 0.76$ & $88 \pm 0.64$ & $78.66 \pm 0.77$ & $89 \pm 0.67$ \\
\hline 25 & $85.66 \pm 0.8$ & $82.66 \pm 0.76$ & $89.39 \pm 0.64$ & $92.66 \pm 0.89$ & $87.83 \pm 0.88$ & $94 \pm 0.65$ \\
\hline 30 & $90.8 \pm 1.6$ & $91.12 \pm 0.82$ & $92.8 \pm 0.89$ & $93.22 \pm 0.9$ & $95.66 \pm 1.6$ & $96.4 \pm 0.5$ \\
\hline Time(min) & F7 & F8 & F9 & F10 & F11 & F12 \\
\hline 0 & 0 & 0 & & 0 & 0 & 0 \\
\hline 5 & $58.5 \pm 0.87$ & 42.160 .46 & $58.4 \pm 0.33$ & 27.70 .46 & 36.890 .45 & 40.020 .55 \\
\hline 10 & $78.3 \pm 0.78$ & $56.83 \pm 0.57$ & $75.6 \pm 0.47$ & $51.5 \pm 0.64$ & $52.22 \pm 0.65$ & $57.36 \pm 0.61$ \\
\hline 15 & $80.33 \pm 0.87$ & $65.5 \pm 0.87$ & $81.56 \pm 0.89$ & $54.1 \pm 0.77$ & $61.10 \pm 0.78$ & $67.24 \pm 0.74$ \\
\hline 20 & $84 \pm 0.98$ & $88.6 \pm 0.76$ & $78.5 \pm 0.89$ & $65.1 \pm 0.82$ & $69.81 \pm 0.81$ & $76.46 \pm 0.89$ \\
\hline 25 & $88.77 \pm 1.1$ & $90.66 \pm 0.9$ & $92.66 \pm 0.83$ & $70.2 \pm 0.9$ & $78.09 \pm 0.91$ & $87.03 \pm 0.90$ \\
\hline 30 & $91.77 \pm 0.9$ & $96.4 \pm 1.1$ & $99.10 \pm 0.67$ & $84.6 \pm 1.2$ & $88.12 \pm 1.0$ & $90.02 \pm 1.1$ \\
\hline
\end{tabular}

${ }^{*}$ Mean \pm SD, $\mathrm{n}=3$.

Table 5: Dissolution profile of ondansetron and optimized formulation (F9)

\begin{tabular}{cccccccc}
\hline \multicolumn{7}{c}{ Time (min) } \\
\hline & 0 & 5 & 10 & 15 & 20 & 25 & 30 \\
\hline Pure drug & 0 & $30 \pm 0.45$ & $47 \pm 0.58$ & $56 \pm 0.76$ & $66 \pm 0.88$ & $76 \pm 0.9$ & $84 \pm 0.99$ \\
F9 & 0 & $58.4 \pm 0.33$ & $75.6 \pm 0.47$ & $81.56 \pm 0.89$ & $88.6 \pm 0.76$ & $92.66 \pm 0.83$ & $99.1 \pm 0.67$ \\
\hline
\end{tabular}

${ }^{*}$ Mean $\pm S D, n=3$.

from various formulations was observed in the following order F9 $>$ F8 $>$ $\mathrm{F} 6>\mathrm{F} 5>\mathrm{F} 4>\mathrm{F} 3>\mathrm{F} 7>\mathrm{F} 2>\mathrm{F} 1>\mathrm{F} 12>\mathrm{F} 11>\mathrm{F} 10>$ Pure drug. Drug release studies of optimized formulation F9 and pure drug were shown in Table 5.

\section{CONCLUSION}

Fast disintegrating tablet is a promising approach with a view of obtaining rapid action of the drug and would be advantageous in comparison to currently available conventional dosage forms. The selection of an ideal batch of Fast disintegrating tablets was made after consideration of the evaluation parameters by dissolution study, disintegration time and wetting time. From the data obtained, it is observed from the formulation containing Isapghol in Formulation F9, shows Disintegration time in 12 seconds and the Percentage drug release is of $99.10 \%$ at the end of 30 min which satisfied all the tablet evaluation parameters for fast disintegrating tablet and show in the Figure 4. Hence looking at all the satisfactory parameters F9 batch is selected as the optimized batch.

\section{ACKNOWLEDGEMENT}

The authors thankful to St. Ann's College of Pharmacy, Vizianagaram, and Andhra Pradesh for helping to carry out this research work.

\section{CONFLICT OF INTEREST}

Authors declare that there is no conflict of interest, so nothing to disclose.

\section{ABBREVIATIONS USED}

ODT- Oral drug therapy; FDT- Fast disintegrating tablets; FTIR - Fourier transform Infrared spectroscopy.

\section{REFERENCES}

1. Kashyap S, Sharma $V$, Singh L. Fast disintegrating tablets: A boon to pediatric and geriatric. Imp J Pharm Cos .2011;1(1):1-11.

2. Swami velmanickam M, Manavalan R, Valliappan K. Mouth dissolving tablets: an overview. IJPSR. 2010;1(12):43-55.

3. Bhowmik D, Chiranjib B, Krishnakanth P, Chandira RM. Fast dissolving tablet: an overview. Journal of chemical and pharmaceutical research. 2009;1(1):163-77.

4. Uppala L, Pranusha P. Development and evaluation of fast disintegrating tablets of ondansetron with natural and synthetic super disintegrating agents. SOJ Pharm Sci.2015;2(3):1-7.

5. Srinivasa rao $\mathrm{B}$, Ramanamma $\mathrm{CH}$, Chowdary KA. Development of self-emulsifying drug delivery system of nebivolol for the improvement of solubility and dissolution.WJPR, 2016;5(10):674-89.

6. Uzondu AL, Onyeriri LO, Okoye El, Anowi CF. Phytochemical and elemental analyses of gum obtained from Treculia Africana seeds. Int J Adv Pharma Sci. 2014;5:1711-6.

7. Sundari PT, Rao KS. Formulation and evaluation of piroxicam and aceclofenac tablets employing Prosolve by direct compression method. Asian Journal of Chemistry. 2009;21(8):5847-50

8. Jachowicz RE, Nürnberg E, Pieszczek B, Kluczykowska B, Maciejewska A Solid dispersion of ketoprofen in pellets. International journal of pharmaceutics. 2000;206(1):13-21.

9. Mohan A, Gundamaraju R. In vitro and in vivo evaluation of fast-dissolving tablets containing solid dispersion of lamotrigine. International journal of pharmaceutical investigation. 2015;5(1):57.

10. Manimaran V, Damodharan N. Development of fast dissolving tablets of nisoldipine by solid dispersion technology using poloxamer 407 and poloxamer 188. J Young Pharm. 2016;8(4):341-9.

11. Rajpurohit $H$, Sharma $P$, Sharma S, Purohit S, Bhandari A. Hordeum vulgare hull in the design of fast disintegrating tablets. Journal of Young Pharmacists. $2011 ; 3(3): 211-5$

12. Pabari RM, Ramtoola Z. Effect of a disintegration mechanism on wetting, water absorption, and disintegration time of orodispersible tablets. Journal of Young Pharmacists. 2012;4(3):157-63.

13. Parmar RB, Baria AH, Tank HM, Faldu SD. Formulation and evaluation of dom- 
peridone fast dissolving tablets. International Journal of PharmTech Research. 2009;1(3):483-7.

14. Puttewar TY, Kshirsagar MD, Chandewar AV, Chikhale RV. Formulation and evaluation of orodispersible tablet of taste masked doxylamine succinate using ion exchange resin. Journal of King Saud University-Science. 2010;22(4):229-40.

15. Koteswari P, Sunium S, Srinivasababu P, Babu GK, Nithya PD. Formulation
Development and evaluation of fast disintegrating tablets of Lamotrigine using liqui-solid technique. International journal of pharmaceutical investigation. 2014;4(4):207-14.

16. Malik K, Arora G, Singh I, Arora S. Lallemantia reylenne seeds as superdisintegrant: Formulation and evaluation of nimesulide orodispersible tablets. International journal of pharmaceutical investigation. 2011;1(3):192.

Article History: Submission Date : 07-04-2017 ; Revised Date : 23-05-2017; Acceptance Date : 11-06-2017.

Cite this article: Mulagada S, Baratam SR. Design and Evaluation of Ondansetron Fast Disintegrating Tablets Using Natural Polymers and Modified Starches as Super Disintegrants for the Enhancement of Dissolution. J Young Pharm. 2017;9(4):519-24. 